\title{
Cezary Pawlonka
}

Uniwersytet Ekonomiczny we Wrocławiu

e-mail: cezary.pawlonka@ue.wroc.pl

ORCID: 0000-0001-8637-3905

\section{WYMÓG ZATRUDNIENIA W FORMIE UMOWY O PRACE W PRAWIE ZAMÓWIEŃ PUBLICZNYCH}

\section{OBLIGATION TO EMPLOY A WORKER AS} A STANDARD FORM IN PUBLIC PROCUREMENT LAW

DOI: $10.15611 / \mathrm{pn} .2018 .540 .10$

Streszczenie: Zjawisko powszechnego zatrudniania w Polsce w ramach umowy-zlecenia niezgodne jest ze strategią rynku pracy Unii Europejskiej - flexicurity. Liczne przykłady nadużyć wobec pracowników pracujących w ramach umów niekodeksowych obrazują niską jakość zatrudnienia w tej formie. W związku z powyższym ustawodawca wprowadził zakaz zatrudniania na podstawie umowy-zlecenia w momencie wystąpienia stosunku pracy - jak przy umowie o pracę, osób realizujących usługi lub roboty budowlane przy zamówieniach publicznych, nawet w przypadku chęci zawarcia takiej umowy przez pracownika. Przepis ten ma zmniejszyć segmentację polskiego rynku pracy. W artykule zbadano historię i znaczenie umowy o pracę w naukach społecznych, zaprezentowano istotę pracy niestandardowej oraz dokonano szczegółowego porównania polskiego rynku pracy z unijnymi celami polityki zatrudnienia. Zaprezentowane $\mathrm{w}$ artykule badania jakościowe autora przeprowadzone zostały wśród osób młodych, pracujących w ramach zatrudnienia cywilnoprawnego.

Słowa kluczowe: Prawo zamówień publicznych, rynek pracy, umowa o pracę, umowa-zlecenie, formy zatrudnienia.

Summary: Common work under the civil law agreement in Poland is incompatible with the flexicurity strategy of the European Union labor market. Numerous examples of abuse against employees working under non-standard work agreement in Poland illustrate the low quality of employment in this form. In connection with the above, the legislator implement a prohibition of employing workers performing services or construction works on public contracts under the civil law contract, even if the employee wishes to conclude such an agreement. This provision has aim to reduce the segmentation of the Polish labor market. The article examines the stories and significance of the employment contract in social sciences. Furthermore has been presented the essence of non-standard work and a detailed comparison of the Polish labor market with the EU employment policy objectives. The author's qualitative research presented in the article was conducted among young people working under civil law employment.

Keywords: Public Procurement Law, labor market, contract of employment, non-typical contract of employment, forms of employment. 


\section{Wstęp}

Ustawa Prawo zamówień publicznych z dnia 22 czerwca 2004 r. art. 29 ust 3a określa obowiązek zatrudnienia przez wykonawcę lub podwykonawcę osób realizujących usługi lub roboty budowlane dla zamawiającego na podstawie umowy o pracę w przypadku wystąpienia stosunku pracy ${ }^{1}$. Uprawnienie zamawiającego z poprzedniej regulacji zostało zastąpione obowiązkiem. Ustawodawca w powyższym artykule podkreśla obligatoryjność zatrudnienia na podstawie stosunku pracy w przypadku charakteru pracy w myśl art. 22 § 1 Ustawy z dnia 26 czerwca 1974 r. - Kodeks pracy. Kodeksowy stosunek pracy występuje w momencie „(...) zobowiązania się pracownika do wykonywania określonej pracy na rzecz pracodawcy i pod jego kierownictwem oraz w miejscu i czasie wyznaczonym przez pracodawcę, a pracodawca - do zatrudniania pracownika za wynagrodzeniem"2. Art. $22 \S 1$ Kodeksu pracy określa również zakaz zastępowania umowy o pracę umową cywilnoprawną w przypadku występowania cech stosunku pracy określonych w art. 22 Kodeksu pracy. Odnoszenie się do powyższej regulacji prawa pracy ma na celu podkreślenie obowiązku dopilnowania standardów zatrudnienia przez pracodawcę $\mathrm{w}$ momencie wykonywania zamówienia.

Praca w ramach umowy o pracę na czas nieokreślony w pełnym etacie jest najpopularniejszą formą zatrudnienia w Polsce i jest uznawana za standardowy rodzaj kontraktu między pracownikiem i pracodawcą. Z kolei umowa-zlecenie ze względu na znacznie mniejszą popularność jest określana jako niestandardowa forma pracy. Niestandardowe formy zatrudnienia, określane również w literaturze terminem pracy elastycznej, dotyczą pracy w każdym innym charakterze niż praca na umowie o pracę w pełnym etacie. Do kodeksowych niestandardowych form zatrudnienia należy praca $\mathrm{w}$ ramach umowy o pracę na czas określony oraz praca $\mathrm{w}$ niepełnym etacie. Do pozakodeksowych form zatrudnienia najczęściej stosowanych w Polsce należy praca w ramach umów cywilnoprawnych - umowa-zlecenie oraz umowa o dzieło. Popularną formą niestandardowego zatrudnienia jest również samozatrudnienie³ ${ }^{3}$

\section{Historia i znaczenie umowy o pracę w naukach społecznych}

Umowę o pracę można analizować w różnych kontekstach, wychodzących poza jej prawne rozumienie. Jest jedną z najważniejszych instytucji regulujących rynek pracy. Zatrudnienie w tej formie ma duże znaczenie ekonomiczne i społeczne dla jednostki,

${ }^{1}$ Ustawa z dnia 29 stycznia 2004 r. - Prawo zamówień publicznych (Dz. U. z 2018 r. nr 19, poz. 1986 z późn. zm.).

${ }^{2}$ Ustawa z dnia 26 czerwca 1974 r. - Kodeks pracy (Dz. U. z 2014 r., poz. 1502 z późn. zm.).

${ }^{3}$ K. Zioło-Gwadera, Formy zatrudnienia stosowane na współczesnym rynku pracy w Polsce, Współczesne Problemy Ekonomiczne nr 13, Wydawnictwo Uniwersytetu Szczecińskiego, Szczecin 2016. 
określa miejsce człowieka w społeczeństwie oraz daje duże poczucie bezpieczeństwa i satysfakcji wynikające z podejmowanej pracy ${ }^{4}$. Analizę relacji pracowniczych regulowanych za pomocą różnych porozumień, warunkujących obowiązki i prawa pracowników i pracodawców względem siebie, można znaleźć w pracach wielu ekonomistów i socjologów. Potrzebę analizy instytucji w kapitalizmie zapoczątkował w ekonomii głównego nurtu T. Veblen. Podważał on pełną racjonalność jednostek i szukał wyjaśnień dla ich zachowań nieefektywnych ekonomicznie w instytucjach prawnych, formalnych i nieformalnych, kształtujących działania ludzi, nazywając to racjonalnością ograniczoną. Analizy T. Veblena oraz następnych instytucjonalistów sprawiły, że ekonomiści zaczęli przywiązywać większą wagę do możliwości aplikacyjnych teorii ekonomii, jak również do takich kluczowych pojęć w współczesnej ekonomii, jak sprawiedliwość podziału kapitału. Po erze kapitalizmu laissez-faire, podbudowanego filozofią m.in. J. Locke'a, D. Hume'a oraz A. Smitha i J.S. Milla, uznających wolność za podstawową wartość, zaczęto zwracać uwagę na wady pełnej wolności w relacjach pracowników i pracodawców ${ }^{5}$.

$\mathrm{Na}$ potrzebę ingerencji państwa w stosunki pracownika i pracodawcy zwracali uwagę m. in. E. Durkheim w swojej polemice z H. Spencerem, Karol Marks w analizie relacji właścicieli kapitału z ich robotnikami oraz $\mathrm{M}$. Weber $\mathrm{w}$ analizie charakteru zatrudnienia urzędników państwowych. W swoich pracach pisali o potrzebie koordynacji przez państwo stosunków między stronami wymiany oraz wskazywali na minusy pozostawiania pełnej swobody warunków zatrudniania pracowników w sytuacji ich znacznie słabszej pozycji do negocjacji ${ }^{6}$. Współczesne teorie interwencji państwa na rynku pracy koncentrują się wokół osoby J.M. Keynesa. Jego prace podkreślały znaczenie aktywnej roli państwa dla prawidłowo działających rynków. Wydana przez niego w 1936 roku książka Ogólna teoria zatrudnienia, procentu i pieniadza miała kluczowe znaczenie dla teorii polityki gospodarczej. Dla J.M. Keynesa gwarancją utrzymania jakości zatrudnienia w gospodarce była praca $\mathrm{w}$ ramach zatrudnienia na podstawie umowy o pracę. Warunki tego kontraktu ustalane w ramach zbiorowych negocjacji, uznano za instrument mający zapewnić pracownikom dobrobyt i bezpieczeństwo społeczne ${ }^{7}$. Kryzys myśli Keynesa z lat 70. XX wieku zapoczątkował okres większej popularności kursów deregulacji rynku pracy, mających swoje podłoże w nurtach teoretycznych będących alternatywą dla myśli brytyjskiego ekonomisty. Monetaryzm i nowa ekonomia klasyczna proponowały mniejszą ingerencję instytucji rynku pracy w umowy pracowników dla

${ }^{4}$ E. Giermanowska, Ryzyko elastyczności czy elastyczność ryzyka, instytucjonalna analiza kontraktów zatrudnienia, Wydawnictwo Uniwersytetu Warszawskiego, Warszawa 2013, s. 28-29.

${ }_{5}^{5}$ B. Klimczak, Wybrane problemy i zastosowania ekonomii instytucjonalnych, Wydawnictwo Akademii Ekonomicznej we Wrocławiu, Wrocław 2006, s. 28-31.

${ }^{6}$ E. Giermanowska, wyd. cyt., s. 30-32.

${ }^{7}$ W. Stankiewicz, Historia myśli ekonomicznej, Polskie Wydawnictwo Ekonomiczne, Warszawa 1987, s. 556-568. 
większej elastyczności i konkurencyjności gospodarki ${ }^{8}$. Współcześnie w nawiązaniu do ich prac nadmierną sztywność rynków pracy określa się jako przeszkodę dla większej efektywności dopasowania popytu i podaży na rynku pracy. Część badaczy otoczenia instytucjonalnego rynku pracy wręcz wskazuje na zbyt niskie wykorzystanie umów niestandardowych, w tym umów-zleceń, w polskiej gospodarce. Mateusz Guzikowski z Szkoły Głównej Handlowej w ekonometrycznym badaniu porównawczym instytucji rynku pracy w krajach transformacyjnych jako powód niewysokiej aktywności zawodowej w Polsce na tle Unii Europejskiej wskazuje niską popularność innych form zatrudnienia niż umowa o pracę9. Podobne wnioski prezentuje Jacek Męcina z Uniwersytetu Warszawskiego, który brak bezpiecznych umów elastycznych, zgodnych z założeniami unijnej polityki zatrudnienia, upatruje jako jeden z powodów niewykorzystywania nieaktywnych zasobów pracy w Polsce ${ }^{10}$.

Zmiany technologiczne i procesy związane z narastającą konkurencją globalną wymuszają na wielu przedsiębiorcach poszukiwanie ograniczania kosztów przez dzielenie się ryzykiem gospodarczym z zatrudnianymi pracownikami. Umowa o pracę zastępowana przez pracodawców niestandardowymi formami zatrudnienia jest wynikiem rosnącej presji na ograniczenie kosztów w gospodarce międzynarodowej, wysoce konkurencyjnej. Umowy alternatywne w obecnym kształcie jednak $\mathrm{z}$ wielu powodów nie są korzystne dla pracowników. $Z$ tego względu ograniczanie przez ustawodawcę nadużywania form niestandardowych w praktyce gospodarczej i promowanie zatrudnienia kodeksowego ma miejsce w wielu sektorach prawa publicznego, również w obszarze zamówień publicznych.

\section{Praca w niestandardowych formach zatrudnienia}

Polski ustawodawca nakłada na uczestników przetargów zamówień publicznych z branży budownictwa wymóg, aby pracownicy zatrudnieni do wykonania zamówienia pracowali $\mathrm{w}$ ramach umowy o pracę $\mathrm{w}$ momencie występowania charakteru pracy kodeksowej. Przepis ten ma na celu wyeliminowanie procederu zastępowania umowy o pracę umowami cywilnoprawnymi w momencie zatrudnienia $\mathrm{z}$ cechami pracy rozumianej zgodnie z przepisami Kodeksu pracy. W 2017 roku według statystyki GUS pracujący w ramach umowy-zlecenia, którzy nie byli zatrudnieni nigdzie w ramach stosunku pracy, stanowili około $6 \%$ całości zatrudnionych w gospodarce narodowej, z czego około $3 \%$ stanowili pracownicy branży budowlanej ${ }^{11}$.

${ }^{8}$ E. Kwiatkowski, Wpływ prawnej ochrony zatrudnienia na rynek pracy w warunkach negatywnego szoku ekonomicznego, Gospodarka Narodowa, https://owe.pte.pl/upload/files/ksiazki/07_Kwiatkowski.pdf.

9 M. Guzikowski, Instytucje rynku pracy w krajach transformacyjnych. Dynamika, interakcje, prawidłowości empiryczne, Oficyna wydawnicza Szkoły Głównej Handlowej, Warszawa 2016, s. 100-103.

${ }_{10}$ J. Męcina, Niewykorzystane zasoby rynku pracy, Nowa polityka rynku pracy, Wydawnictwo ASPRA-JR, Warszawa 2013, s. 7-16.

${ }^{11}$ Pracujacy w gospodarce narodowej w 2017 roku, Wydawnictwo Głównego Urzędu Statystycznego, Warszawa 2018. 
Proces naruszenia art. 22 Kodeksu pracy - zawieranie umów cywilnoprawnych w warunkach charakterystycznych dla stosunku pracy, zostało zaobserwowane podczas kontroli Państwowej Inspekcji Pracy wśród 16,8\% (79 z 473) pracodawców w branży budownictwa, u których przeprowadzono kontrolę. Wśród badanych branż odsetek ten był najwyższy w branży budownictwa ${ }^{12}$.

Zapis ustawodawcy w Prawie zamówień publicznych miał zapobiegać obniżaniu szacowanych kosztów wykonania zlecenia w ofercie przetargowej oferenta kosztem jakości warunków pracy zatrudnionych osób ${ }^{13}$. Budowanie przewagi kosztowej przez zatrudnienie w niestandardowych formach przyczyniało się do częstego narzucania pracownikom form pozakodeksowych, które w większości przypadków są dla nich niekorzystne. Zatrudnienie w formie nietypowej jest opisywane w teorii rynku pracy jako zatrudnienie drugiego segmentu. Silna ochrona umów formalnych, typowych powoduje, że trudno jest awansować do pierwszego segmentu, co w następstwie skutkuje dualizacją rynków pracy ${ }^{14}$. Polaryzacja rynku pracy przebiega przez granicę stabilności zatrudnienia u pracodawcy. O polaryzacji rynku pracy decyduje stabilność zatrudnienia u pracodawcy. Podział na dwa rynki pracy - jeden z pewnymi, stałymi umowami i drugi z umowami z mniejszą ochroną zatrudnienia - jest szczególnie widoczny w branżach z liczną reprezentacją zawodów niskich kwalifikacji, takich jak sektor budowlany ${ }^{15}$.

Według opinii zarówno pracowników, jak i pracodawców forma zatrudnienia inna niż umowa o pracę jest określana jako mniej pożądana przez pracobiorców. W badaniach Marcina Kucharskiego z Uniwersytetu Warszawskiego 70\% ankietowanych wskazywało, że formy zatrudnienia nietypowego obniżają bezpieczeństwo socjalne pracowników. Do najważniejszych wad pracy w takim charakterze ankietowani zaliczali brak ochrony przed zwolnieniami, brak przestrzegania zasad BHP, brak możliwości skorzystania z urlopu wypoczynkowego oraz przedmiotowe traktowanie $^{16}$. W badaniach Samorządu Województwa Dolnośląskiego wykonywanych we współpracy z Ryszardem Szarfenbergiem badani pracodawcy deklarowali zwolnienie około $40 \%$ pracowników pracujących na umowach niestandardowych w przypadku ewentualnej likwidacji umów niestandardowych i obowiązku zatrudniania wszystkich pracowników w stosunku pracy (umowa o pracę na czas nieokreślony).

12 Sprawozdanie Głównego Inspektora Pracy z działalności Państwowej Inspekcji Pracy - 2017, Warszawa 2018, s. 75-77.

13 https://www.uzp.gov.pl/baza-wiedzy/interpretacja-przepisow/opinie-archiwalne/opinia-dotyczaca-art.-29-ust.-3a-ustawy-pzp (dostęp 2.12.2018 r.).

14 T. Boeri, J.V. Ours, Ekonomia niedoskonatych rynków pracy, Wydawnictwo Oficyny Wolters Kluwer, Warszawa 2011, s. 277278; Flexicurity w Polsce, diagnoza i rekomendacje, red. E. Kryńska, Warszawa 2009, s. 137-146.

${ }^{15}$ E. Kryńska, E. Kwiatkowski, Podstawy wiedzy o rynku pracy, Wydawnictwo Uniwersytetu Łódzkiego, Łódź 2013, s. 207-211.

${ }^{16}$ M. Kucharski, Koncepcja flexicurity a elastyczne formy zatrudnienia na polskim rynku pracy, Instytut Polityki Społecznej, Warszawa 2012, s. 250-254. 
Ankietowani do wad umów elastycznych zaliczali ograniczoną możliwość uzyskania kredytu oraz niższe zarobki i brak możliwości awansu. W tym samym badaniu przedsiębiorcy także określają zatrudnienie na umowach elastycznych jako mniej korzystne dla swoich pracowników ${ }^{17}$. Pracodawcy zatrudniają $\mathrm{w}$ charakterze pracy niestandardowej głównie ze względu na możliwość ograniczania kosztów swojego przedsiębiorstwa. Niejednokrotnie pracodawcy nie pozostawiają wyboru pracobiorcom i oferują pracę tylko w formie niestandardowej. Według badań Głównego Urzędu Statystycznego 80,2\% osób zatrudnionych na umowach cywilnoprawnych nie miało wpływu na wybór zatrudnienia w formie niepracowniczej; podobny odsetek wskazują badania Samorządu Dolnośląskiego ${ }^{18}$.

Niestandardowe formy pracy, takie jak umowa cywilnoprawna, dają jednak pracodawcy i pracownikowi większą elastyczność kształtowania czasu pracy. W idealnym założeniu obydwie strony mają w takim wypadku dużą większą łatwość dopasowania szczegółów zatrudnienia. Charakter umów cywilnoprawnych w swoim założeniu traktuje pracownika i pracodawcę jako równorzędne podmioty, dlatego to również pracownik ma mieć przy tej umowie możliwość wykonania pracy w dogodnym dla siebie czasie, bez zwierzchnictwa i bez określonego miejsca wykonania tego zadania. Dlatego dla pracowników największe potencjalne korzyści z umów niestandardowych to możliwość łączenia pracy z życiem prywatnym oraz większa swoboda organizacji czasu pracy. Te same plusy zatrudnienia $\mathrm{w}$ formie niestandardowej dostrzegają ankietowani pracownicy ${ }^{19}$. Wykorzystywane w odpowiedni sposób do wykonania mniejszych lub średnich okresowych prac eksperckich, dla osób o wysokich kwalifikacjach, bez obowiązku kontrolowania ich przez kierownika, mogą być najbardziej pożądane. Praca w ramach umów niestandardowych jest również określana jako szansa dla grup osób szczególnie zagrożonych bezrobociem, takich jak osoby starsze, młode, wchodzące na rynek pracy, osoby niepełnosprawne i osoby z niskimi kwalifikacjami. Osoby zatrudniane dorywczo w formie umowy zlecenia mogą stanowić dla pracodawcy okresową pomoc sezonową lub pomoc do wykonania jednego z etapów prac. W określonych sytuacjach niestandardowe formy pracy mogą być dla obydwu stron wygodniejsze ${ }^{20}$. W sytuacji obowiązku określenia przez oferenta charakteru pracy każdego pracownika mającego wykonać zamówienie, możliwość błędnego założenia charakteru pracy przy wykonaniu zlecenia danego pracownika przez oferującego jest bardzo prawdopodobne ${ }^{21}$.

17 Elastyczne formy zatrudnienia - skutki społeczne i ekonomiczne, Wydawnictwo „Obserwatorium Dolnośląskiego Rynku Pracy i Edukacji”, Wrocław 2013, s. 50-53, 157-158.

18 Tamże, s. 159; GUS, Notatka informacyjna. Pracujacy w nietypowych formach zatrudnienia, Warszawa 2016, s. 4.

19 M. Kucharski, Koncepcja flexicurity a elastyczne..., s. 254.

${ }^{20}$ C. Sadowska-Snarska, Elastyczne formy pracy jako instrument ułatwiajacy godzenie życia zawodowego z rodzinnym, Wydawnictwo Wyższej Szkoły Ekonomicznej w Białymstoku, Białystok 2006, s. 17-20.

${ }^{21}$ https://www.prawo.pl/samorzad/klopotliwy-wymog-zatrudnienia-na-umowe-o-prace-wnowelizacji-pzp,232298.html (dostęp 3.12.2018 r.). 
Faktem jest, że wraz ze wzrostem ochrony zatrudnienia spada elastyczność formy zatrudnienia. Szczególną uwagę na to zwraca w teorii rynku pracy Eugeniusz Kwiatkowski, tłumacząc potrzebę elastyczności kadrowej pracodawcy zmiennością popytu na pracę przedsiębiorstw ,zwłaszcza w okresie dekoniunktury ${ }^{22}$. Ustawodawca w art. 734-751 Kodeksu cywilnego nie uszczegóławia warunków pracy w ramach umowy zlecenia, co czyni tę umowę bardziej elastyczną niż umowa o pracę. Kodeks cywilny w przeciwieństwie do Kodeksu pracy nie zapisuje wymogu wskazania przez zlecającego miejsca pracy i czasu, nie zapisuje podrzędności wykonującego zlecenie przez obowiązek zwierzchnictwa zlecającego, wskazuje natomiast, że wykonujący zlecenie może przekazać wykonanie zlecenia osobie trzeciej oraz może odstąpić od umowy w każdym czasie ${ }^{23}$. Plusy takich rozwiązań dostrzegają zarówno pracownicy, jak i pracodawcy. W badaniu Samorządu Województwa Dolnośląskiego ankietowani pracownicy, oprócz wskazywanych wcześniej zalet umów niestandardowych, dotyczących możliwości opieki nad dziećmi i możliwości wygospodarowania większej ilości czasu wolnego, wskazywali m.in. na sposobność pracy u kilku pracodawców i możliwość uzyskiwania większych zarobków. Formy pracy niestandardowej, w tym pracy na podstawie umowy zlecenia, przede wszystkim oceniają pozytywnie osoby młode, poniżej 29 roku życia - 54\% z nich wskazywało, że takie umowy mogą być dla nich korzystne. Ten sam raport z badań wskazuje, że $80 \%$ pracodawców traktuje formy pracy niestandardowej jako dla nich korzystne ${ }^{24}$.

\section{Badania jakościowe wśród młodych osób zatrudnionych w ramach form niestandardowych}

W celu zbadania opinii o pożądanej formie umów niestandardowych zostały wykonane pilotażowe badania jakościowe wśród osób pracujących lub mających doświadczenie w pracy w ramach umów pozakodeksowych, w zgodzie z założeniami teorii ugruntowanej. Prezentowane analizy stanowią wstęp do przyszłych szerszych badań jakościowych i ilościowych w tym samym obszarze. Wstępne badanie fokusowe zostało wykonane na 3 grupach osób młodych - w wieku 20-22 lat, mających doświadczenie $\mathrm{w}$ pracy $\mathrm{w}$ ramach umów niestandardowych. W zogniskowanych wywiadach grupowych przeważały kobiety, każda grupa liczyła 20 osób, łącznie zaś przebadanych w grupach zostało około 60 osób. 5 wywiadów pogłębionych przeprowadzono z osobami w wieku 24-28 lat, z dwiema kobietami oraz z trzema mężczyznami, wszyscy byli zatrudnieni w ramach umów-zleceń, pracowali jednak de facto w stosunku umowy o pracę. Respondenci byli w trakcie studiów albo skoń-

${ }^{22}$ E. Kwiatkowski, Bezrobocie. Podstawy teoretyczne, Wydawnictwo Naukowe PWN, Warszawa 2007, s. 295.

${ }^{23}$ Ustawa z dnia 23 kwietnia 1964 r. - Kodeks cywilny (Dz. U. z 2018 r., poz 1025, 1104, 1629, 2073).

${ }^{24}$ Elastyczne formy zatrudnienia - skutki społeczne..., s. 52. 
czyli studia licencjackie lub magisterskie. Dobór próby był celowy - osoby młode stanowią grupę docelową badania, ponieważ wśród nich jest największy odsetek osób zatrudnianych w formie niestandardowej.

Pytanie badawcze dotyczyło istotności instytucji rynku pracy dla osób z pokolenia millenialsów - pytano, co ma większe znaczenie w pracy na danym stanowisku: bezpieczeństwo socjalne i ekonomiczne czy elastyczność zatrudnienia. Największy odsetek umów niestandardowych z wyboru występuje właśnie wśród osób młodych. Wybór ten może być podyktowany wyłącznie obecną sytuacją, okresem studiów, przejściową formą zatrudnienia w drodze do pracy standardowej, ale może też oznaczać dla nich wybór docelowy, na dłuższy czas. Praca w ramach umowy niestandardowej zarówno teraz, jak i w zakładanej przyszłości może być dla pokolenia millenialsów akceptowaną alternatywą dla umowy standardowej. Prezentowane badania mogą być przydatne przy ocenie zmian opisywanych w artykule $\mathrm{w}$ prawie zamówień publicznych. Pokolenie urodzone w latach 1980-2000, określane mianem millenialsów, według danych firmy badawczej PwC w roku 2020 będzie stanowić aż 50\% siły roboczej ${ }^{25}$, a według analiz amerykańskiego banku Merrill Lynch do roku 2025 $-75 \%{ }^{26}$. Osoby te mają zupełnie inne wymagania co do relacji z pracodawcą i mogą oczekiwać innych rozwiązań prawnych dotyczących elastyczności i bezpieczeństwa pracy. Przedstawione badanie pokazuje opinię osób urodzonych w latach 1990-2000, młodszej połowy omawianego pokolenia. Opinie osób urodzonych w innej dekadzie, ale uznawanych za jedno pokolenie, mogą być podobne, aczkolwiek mogą też różnić się w pewnych kwestiach.

W opiniach respondentów potrzeba łączenia elastyczności i bezpieczeństwa społecznego wymaga od nich wielu kompromisów względem pracodawców. Słaba ochrona zatrudnienia umów niestandardowych powoduje, że cześć osób w wyniku złych doświadczeń traci zaufanie wobec pracodawców i elastycznego rynku pracy. Jedna $\mathrm{z}$ ankietowanych wprost przytacza przykład nierzetelności pracodawców na polskim rynku pracy: Już raz zostałam oszukana. Miałam podpisać umowę-zlecenie, pracowatam tam półtora miesiaca, po czym nie zobaczyłam ani złotówki. Respondentce nie zależało na podpisaniu umowy-zlecenia przed rozpoczęciem pracy, ponieważ nie dostrzegała ona dużej różnicy w pracy na umowie-zleceniu lub bez umowy - stopień zabezpieczenia był oceniany przez nią jako równie znikomy. Ankietowani pracujący w ramach umów niestandardowych dostrzegają nierówne prawa pracowników kodeksowych i pozakodeksowych. Jednym z przejawów dyskryminacji osób zatrudnionych w ramach umów zlecenia jest brak możliwości skorzystania z płatnego urlopu: Jeżeli pracuję na wakacjach 3 miesiace, to też bym chciała mieć ten tydzień urlopu płatnego. Inny ankietowany pracujący na umowie-zleceniu w branży

25 https://www.pwc.de/de/prozessoptimierung/assets/millennials-at-work-2011.pdf (16.12.2018 r.).

${ }^{26}$ Osoby w wieku 18-30 lat, urodzone w latach 1980-2000, są określane w teorii socjologii jako pokolenie millenialsów lub pokolenie Y; cechują się zupełnie innym podejściem do pracy niż pokolenie ich rodziców baby boomers. Nie planują pracy dla jednego pracodawcy całe życie, cenią sobie życie prywatne, a sens ich pracy jest dla nich bardzo ważny. 
gastronomicznej umówił się w formie ustnej z pracodawcą na możliwość wykorzystania urlopu płatnego, lecz przyznaje, że tak jak większość pracowników w wyniku natłoku pracy w przedsiębiorstwie nie wykorzystał urlopu.

Na długie godziny pracy, brak dni wolnych oraz trudne obowiązki zawodowe wskazują również zatrudnieni $\mathrm{w}$ formach niestandardowych, określani również w tym badaniu jako pracownicy tymczasowi, badani w ramach wywiadu grupowego Rafała Mustery z Uniwersytetu Śląskiego ${ }^{27}$ : Na pracowników tymczasowych spada więcej obowiązów niż na pracowników statych, pelnoetatowych. Natomiast pracownicy tymczasowi musza zostawać po godzinach, maja trudności z uzyskaniem wolnego, dostaja najgorsze prace, często spotkamy się także z motywacja negatywną: ,,jak tego nie zrobisz, to cię zwolnimy”. Te same badania wskazują na ograniczone możliwości udziału w szkoleniach w ramach zatrudnienia niestandardowego oraz brak dodatkowych świadczeń socjalnych. Kolejny problem opisywany w badaniach Mustery jest związany z bezpieczeństwem ekonomicznym: Inny badany podkreślit problem $w$ dostępie do kredytu bankowego - co z kolei uniemożliwia bądź utrudnia usamodzielnienie się.

Badania własne autora wskazują również na przymusowy charakter zatrudnienia $\mathrm{w}$ formie niestandardowej. Jeden $\mathrm{z}$ respondentów pracujący $\mathrm{w}$ firmie $\mathrm{z}$ branży kreatywnej wskazuję na brak możliwości wyboru formy zatrudnienia w momencie posiadania niskich kwalifikacji: U mnie w pracy tylko osoby z duża pozycja negocjacyjna, z dużym doświadczeniem otrzymuja umowe o pracę na wejście, reszta musi ja sobie wywalczyć. W odpowiedzi na pytanie o wzrost siły negocjacyjnej pracowników w wyniku spadku bezrobocia w Polsce respondenci zastrzegają, że sytuacja, w której pracownik może w większym stopniu kształtować warunki zatrudnienia w ramach form niestandardowych, dotyczy tylko wybranych regionów kraju: $\mathrm{Na}$ tak dużych rynkach jak Wrocław istnieje rynek pracownika, w matych miastach do 10,15 tysięcy - często monopol ma jeden duży pracodawca. Do plusów umów niestandardowych zaliczana jest możliwość pracy w różnych obszarach, w kilku miejscach: Praca na kilku umowach umożliwia zdobycie różnego doświadczenia, co może być interesujące dla pracodawców. Dla respondentów z młodego pokolenia ważna jest możliwość elastycznego kształtowania godzin pracy: Wiadomo, różne sa przypadki - lepiej mieć jakiś wptyw na godziny pracy, niż tak jak teraz najczęściej nie mieć żadnego. Respondenci wskazywali też na mit elastyczności czasu pracy w ramach umów-zleceń i niepełnoetatowych form: Często się kończy tak, że się pracuje dhuzej, niż wskazywała umowa; może się skończyć tak, że będzie się miało dwa petne etaty (zamiast dwóch umów na pót etatu).

Zarobki przy umowach niestandardowych są określane przez ankietowanych w badaniach społecznych jako większe lub mniejsze niż przy standardowym zatrudnieniu, w dużej mierzę zależności to od tego czy są wypłacane godziny nadliczbowe

${ }^{27}$ R. Muster, Elastyczne formy pracy w opiniach pracowników nieetatowych, Opuscula Sociologica, nr 1, Katowice 2012. 
w miejscu pracy. Wynika to z różnorodności ustalanych z pracodawcami warunków i szczegółów poszczególnych umów zatrudnienia, ponieważ w przeciwieństwie do umowy o pracę ich kształt nie jest najczęściej negocjowany w ramach układów zbiorowych, ale indywidualnie. Osoby z dużym wykształceniem lub pracujące w godzinach przekraczających jeden etat mogą zarobić więcej niż na umowie o pracę, gdzie nadgodziny i praca w nocy lub święta najczęściej są nieopłacalne dla pracodawcy. Część zarobków dla osób pracujących w formach pozakodeksowych może być również wypłacana $\mathrm{w}$ ramach sektora nieformalnego, płacona bezpośrednio pracownikom, bez opodatkowania.

Raport PIP wskazuję na liczne przypadki zawierania umów-zleceń tuż przed wykonywanymi kontrolami. Podobne wnioski prezentują respondenci badań własnych: Chciałabym pracować na umowie-zleceniu lub nawet bez umowy, bo wtedy dostaje się więcej pieniędzy, jednak to zależy, jak bardzo ta praca jest niebezpieczna. Relatywizacja plusów form innych niż standardowe jest też dostrzegana przy pracy w formie samozatrudnienia: Praca $w$ ramach samozatrudnienia dała mi duże dochody przez 7 miesięcy, teraz po zakończeniu wspótpracy wiem, że muszę odjąc ten dochód przez te kilka miesięcy, kiedy będę bez pracy. Podobne zdanie na temat pracy na samozatrudnieniu miał respondent wykonujący zawód doradcy finansowego: Wole nie dostawać umowy o pracę, najchętniej chciałbym pracować w ramach kontraktu $B 2 B$ (Business to Business - samozatrudnienie), bo wole sam decydować, na co przeznaczać moje pieniądze, samemu zabezpieczyć swoją emeryturę. Możliwość większych zarobków przez dany okres musi być jednocześnie podzielona przez czas, kiedy w wyniku nagłej utraty kontraktu z pracodawcą nieprzygotowany pracownik staje się bezrobotny i musi szukać natychmiastowo kolejnej pracy tymczasowej.

Od wysokich zarobków przy umowie-zleceniu lub w ramach samozatrudnienia należy również odjąć brak płatnego urlopu wypoczynkowego. Jest to związane ze zjawiskiem prac sezonowych, okresowych, popularnych w tzw. gig economy ${ }^{28}$, gdzie pracownik zmienia pracę lub podejmuję się wielu prac jednocześnie, często rezygnując z jednej i podejmując kolejne ${ }^{29}$. Taka praca cechuję się dużą elastycznością, ale osiągniętą kosztem m.in. płatnego urlopu, gwarantowanego w polskim prawie jedynie w przypadku umowy o pracę, okresu wypowiedzenia oraz gwarancji stałości zatrudnienia $\mathrm{i}$ innych. Taka sytuacja jest również niekorzystna dla pracodawców, którzy wielokrotnie ponoszą koszty znalezienia odpowiedniego wykonawcy pracy i jego przeszkolenia.

${ }^{28}$ Gig economy: rodzaj prac we współczesnej gospodarce usług, bazujących na kilku tymczasowych kontraktach, wykonywanych oddzielnie, za które otrzymuje się niezależne od poszczególnych prac wynagrodzenie.

${ }^{29}$ www.recode.net/2016/10/26/13349498/gig-economy-profits-workers-desperate-serviceslabor (dostęp 18.12.2018 r.). 


\section{Umowa o pracę w ustawie Prawo zamówień publicznych w kontekście polityki rynku pracy Unii Europejskiej}

Dychotomia jakości pracy w formie standardowej i niestandardowej jest problemem wielu krajów Unii Europejskiej ${ }^{30}$. Wyrazem walki z tym zjawiskiem jest zapisanie w prawie Unii Europejskiej polityki zatrudnienia zgodnego z modelem flexicurity. Pojęcie to powstało jako połączenie słów flexible (elastyczność) i security (bezpieczeństwo). Model ten został opracowany przez T. Wilthagena i F. Trosa i wprowadzony z powodzeniem w Danii i Holandii. Poza elastycznym rynkiem pracy, ważne $\mathrm{w}$ tym modelu jest aktywne podejście do polityki rynku pracy państwa oraz szeroki świadczeń socjalnych oferowanych przez państwo osobom pracującym. W wyniku połączenia tych 3 elementów kraje te osiągnęły bardzo wysoki poziom aktywności zawodowej, bez uszczerbku dla poziomu ich bezpieczeństwa społecznego ${ }^{31}$. Polityka flexicurity obecna jest w prawie wspólnoty już od roku 1997 i została wprowadzona w celu wyeliminowania podziału rynku pracy w Unii Europejskiej na niestandardowe, mniej bezpieczne formy zatrudnienia, $\mathrm{i}$ formy standardowe z pełnymi prawami socjalnymi. W 2001 roku polityka ta została wpisana na stałe do Europejskiej strategii zatrudnienia w dokumentach strategii lizbońskiej. Po okresie kryzysu gospodarczego w Unii Europejskiej z końca pierwszej dekady lat dwutysięcznych polityka flexicurity wprowadzana w modelu duńskim i holenderskim okazała się nieskuteczna-głównie z powodu wdrażania elastyczności rynku pracy, bez pozostałych dwóch elementów modelu. Polityka flexicurity została uznana za współwinnego zmniejszenia uregulowań dotyczących zwalniania pracowników w krajach wspólnoty, co mogło być skutkiem znacznego wzrostu bezrobocia w tamtym okresie ${ }^{32}$. Wskutek tego polityka uelastyczniania rynku pracy dla poprawy konkurencji Unii Europejskiej została poddana rewizji w wielu państwach kontynentu. Liczne przykłady krajów unijnych, szczególnie krajów potransformacyjnych i krajów Południa, m.in. Hiszpanii $^{33}$, a także Węgier ${ }^{34}$ i Polski, pokazują, że polityka flexicurity prowadzona jest głównie jako polityka zwiększonej elastyczności, bez gwarancji bezpieczeństwa społecznego i ekonomicznego ${ }^{35}$. Praca w niestandardowych formach jest również

${ }^{30}$ Polityka rynku pracy, teoria i praktyka, red. M. Frączak, Polskie Wydawnictwo Naukowe, Warszawa 2015, s. 70-72.

${ }^{31}$ T. Wilthagen, F. Tros, The concept of ,flexicurity”. A new approach to regulating employment and labour markets, Flexicurity Research Paper, 2003/2004, s. 4.

32 A. Gładzicka-Janowska, Flexicurity - koncepcja i jej weryfikacja w okresie kryzysu i spowolnienia po 2007 roku, Optimum. Studia Ekonomiczne, nr 3(63), red. T. Poskrobko, Białystok 2013, s. 206-210.

33 Á.L. Sánchez Iglesias, [w:] Elastyczny rynek pracy i bezpieczeństwo socjalne, flexicurity po polsku?, red. M. Rymsza, Wydawnictwo Instytutu Spraw Publicznych, Warszawa 2005, s. 138-140.

${ }^{34}$ T. Gyulavári, G. Kártyás, The hungarian flexicurity pathway? New Labour Code after Twenty Years in the Market Economy, Pazmany Press, Budapest 2015, s. 83-85.

${ }_{35}$ Enabling social Europe, red. B.V. Maydell, Springer, Berlin 2006, s. 112-113; S. Daniłowska, Duńskie państwo dobrobytu a koncecja flexicurity, Instytut Polityki Społecznej, Warszawa 2016, s. 185-194. 
wiązana z nasilającym się zjawiskiem prekariatu ${ }^{36} \mathrm{i}$ wzrostem ubóstwa osób pracujących $^{37}$, zarówno w Polsce, jak i w innych krajach Europy i Świata ${ }^{38}$. W Hiszpanii $\mathrm{z}$ racji silnej segmentacji rynków pracy $\mathrm{w}$ wyniku wprowadzenia polityki flexicurity, polityka ta została przemianowana na politykę flexiprecarity.

Wzmożona troska wspólnoty o standardy rynku pracy w okresie po kryzysie roku 2009 znalazła swoje odzwierciedlenie w ustawodawstwie Unii dotyczącym zamówień publicznych ${ }^{39}$. Dyrektywa Parlamentu Europejskiego i Rady wymaga bowiem od krajowego systemu zamówień publicznych dostosowania swoich praw do standardów unijnych - przez poszanowanie obowiązków prawa socjalnego i prawa pracy ustanowionego w przepisach Unii Europejskiej. Ten akt prawny w szczególny sposób podkreśla potrzebę bezpieczeństwa i jakości pracy, jaką gwarantuje ochrona prawa pracy. Jest jednocześnie ważnym głosem w dyskusji nad korektą strategii flexicurity w Unii Europejskiej, której pokłosiem była znaczna liberalizacja form zatrudnienia na rynkach pracy krajów spójności.

Przejawem wdrażania polityki poprawiania bezpieczeństwa ekonomicznego i społecznego umów niestandardowych w Polsce było wprowadzenie w 2017 roku uaktualnianej w każdym roku stawki minimalnego wynagrodzenia godzinowego dla pracy w formie umowie-zlecenia ${ }^{40}$. Kwota ta jest zbieżna $\mathrm{z}$ kwotą wynagrodzenia minimalnego ustalanego dla umowy o pracę w danym roku. Podobny cel miało „oskładkowanie” każdej z umów-zlecenia składkami społecznymi w 2016 roku do kwoty minimalnego wynagrodzenia, wynikające $\mathrm{z}$ nowelizacji ustawy o systemie ubezpieczeń społecznych ${ }^{4}$. Ustawodawca wprowadził poniższy zapis, aby wykluczyć nadużycia zleceniodawcy polegające na zawieraniu dwóch umów - jednej na wyższą i drugiej na niższą kwotę wynagrodzenia, w celu opłacania niższych składek na ubezpieczenia społeczne zleceniobiorców.

${ }^{36}$ Pojęcie prekariatu pochodzi od łacińskiego słowa precarius oznaczającego niepewność. Jest to grupa społeczna, do której zalicza się osoby należące do nisko płatnego, niestabilnego i pozbawionego świadczeń socjalnych segmentu rynku pracy. Z. Bauman określa prekariat jako grupę społeczną, a nie klasę, ponieważ prekariusze nie mają wspólnej zbiorowej tożsamości w znaczeniu klas według K. Marksa.

${ }^{37}$ Osoby biedne pracujące (working poor) są to pracownicy, którzy pomimo podjęcia pracy nie są w stanie wyjść z ubóstwa, nie posiadają wystarczającego wynagrodzenia, aby zaspokoić potrzeby na poziomie minimalnym. W takim wypadku pełne zatrudnienie w gospodarce nie jest wystarczające dla likwidacji ubóstwa.

${ }^{38}$ G. Standing, 2014, Prekariat: Nowa niebezpieczna klasa, Wydawnictwo Naukowe PWN, Warszawa, s. 44; rszarf.ips.uw.edu.pl/pdf/workingpoor.pdf (dostęp 18.12.2018 r.).

39 Art. 18 ust. 2 Dyrektywy Parlamentu Europejskiego i Rady 2014/24/UE z dnia 26 lutego 2014 r. w sprawie zamówień publicznych, uchylającej Dyrektywę 2004/18/WE (Dz. Urz. UE L 94 z 28.03.2014, str. 65, z późn. zm.).

${ }^{40} \mathrm{https}$ ://www.gov.pl/web/rodzina/placa-minimalna-w-gore (dostęp 02.12.2018 r.).

${ }^{41} \mathrm{https} / /$ www.gov.pl/web/rodzina/informator-zmiany-w-oskladkowaniu-umow-zlecenia (dostęp 13.12.2018 r.). 
Praca w Polsce w formach niestandardowych zwiększa ryzyko deprywacji bezpieczeństwa socjalnego zatrudnionych. Taki model pracy nie jest zgodny z Europejską strategią zatrudnienia, która ma na celu poprawę konkurencyjności unijnej gospodarki przez większą elastyczność rynku pracy, ale bez uszczerbku dla warunków pracy. Instrumenty poprawiające gwarancję bezpieczeństwa pracy w formie niestandardowej nie likwidują segmentacji zatrudnienia na polskim rynku pracy. Proces ten jest intensyfikowany wraz z nowym modelem organizacji, mającym na celu ograniczanie kosztów za pomocą podziału zadań i stanowisk na peryferyjne, możliwe do wykonania poza jej strukturą, i te kluczowe, potrzebne niezbędnie w strukturze przedsiębiorstwa. Osoby pracujące $\mathrm{w}$ formie niestandardowej nie są zaliczane do grona pracowników należących do centrum przedsiębiorstwa (core $)^{42}$. Osoby zatrudnione na umowach niestandardowych określa się związku z tym również jako umowy tymczasowe wiąże się to z podejściem krótkoterminowym do tych pracowników, możliwością ich natychmiastowej wymiany lub redukcji w budżecie przedsiębiorstwa. Szczególne wyzwanie w tym obszarze, zwłaszcza w omawianej branży budowlanej, niesie ze sobą zatrudnianie obcokrajowców, którzy niejednokrotnie są traktowani jako tańsza tymczasowa forma zastępcza dla stałych pracowników. Według danych agencji zatrudnienia Progres za 2017 rok, bazujących na próbie 23641 pracowników tymczasowych w Polsce i na Ukrainie, około 70\% obcokrajowców pracujących w Polsce jest zatrudnionych w ramach umowy-zlecenia ${ }^{43}$.

Dodatkowo proces gwarancji większego bezpieczeństwa społecznego i ekonomicznego umów niestandardowych nie zbiega się z jednoczesnym uelastycznianiem umów kodeksowych o pracę. To powoduje, że pracę w formie standardowej uznaje się za wyjątkowo nieelastyczną, sztywną, i to zarówno dla pracownika, jak i dla pracodawcy. Wynika to z dużej rozbieżności bezpieczeństwa umowy w formie standardowej i niestandardowej, co stanowi jednocześnie o ich stopniu elastyczności. Dodatkowo znaczna różnica w kosztach pozapłacowych, wynikająca m.in. z systemu opodatkowania poszczególnych form zatrudnienia, powoduje to, że dla przedsiębiorców zatrudnienie $\mathrm{w}$ ramach umowy o pracę wiążę się z dużą inwestycją w pracownika i jego miejsce pracy ${ }^{44}$. Potwierdzają to badania własne autora, w których respondenci przedstawiali przykłady traktowania umowy o pracę w mniejszych firmach jako formy szczególnej gratyfikacji, dla specjalistów wyższego szczebla. Długi okres wypowiedzenia przy umowie o pracę może być dla pracownika i pracodaw-

${ }^{42}$ D. Bąk-Grabowska, Zarządzanie zasobami ludzkimi w warunkach stosowania niestandardowych form zatrudnienia, Wydawnictwo Uniwersytetu Ekonomicznego we Wrocławiu, Wrocław 2016, s. 33-34.

${ }^{43}$ https://grupaprogres.pl/ukraincy-pracuja-krotko-ale-intensywnie/ (dostęp 18.12.2018 r.).

${ }^{44}$ D. Bąk-Grabowska, K. Piwowar-Sulej, Flexicurity na tle założeń europejskiego i amerykańskiego modelu rynku pracy oraz polskich uwarunkowań, Nauki Społeczne, nr 1(5), red. J. Chumiński, Wydawnictwo Uniwersytetu Ekonomicznego we Wrocławiu, Wrocław 2012, s. 17; A. Laszek, W. Wojciechowski, Propozycje zmian w zakresie umów o pracę: kodeksowych i cywilnoprawnych, Forum Obywatelskiego Rozwoju, nr 3, Warszawa 2015, s. 2-8. 
cy niedogodnością w przypadku chęci natychmiastowego zakończenia współpracy przez obydwie strony. Warto dodać, że okres wypowiedzenia przy umowie o pracę w Polsce jest trzykrotnie dłuższy, przy czteroletnim stażu pracy, niż w Niemczech i Wielkiej Brytanii. W Stanach Zjednoczonych oraz w Danii natomiast okres wypowiedzenia nie istnieje w ogóle ${ }^{45}$.

\section{Podsumowanie}

W poszczególnych przypadkach zawarcie umowy innej niż umowa o pracę jest pożądane, mimo występowania cech pracy kodeksowej, ze względu na znacznie większą swobodę współpracy obydwu stron wymiany. W zawężonej próbie osób młodych potwierdzają to badania własne autora. Nieodosobnione są również przypadki, gdy trudno jest określić, czy dany rodzaj pracy zawiera się w rozumieniu stosunku pracy art. 22 Kodeksu pracy - na przykład w przypadku specjalistów i kierowników, którzy nie świadczą pracy, chociażby ze względu na brak podległości innym osobom. W takim przypadku jest możliwe zatrudnienie takich osób na umowie-zleceniu, aby wykonywały zadania wyznaczone w przetargu zamówień publicznych. Problemem będzie jednak dopilnowanie braku występowania pozostałych cech pracy kodeksowej.

Plusy elastyczności umów pozakodeksowych przysłaniają praktyki wykorzystywania siły negocjacyjnej pracodawcy na polskim rynku pracy. Duża dowolność kształtowania stosunków pracy pomiędzy zleceniodawcą i zleceniobiorcą, na przykład w obszarze wynagradzania, urlopów wypoczynkowych, jak również bezpieczeństwa zasad BHP, skutkuje w Polsce dużymi nadużyciami w postaci wykorzystywania umów-zleceń do wykonywania pracy w charakterze kodeksowym, tylko z znacznie mniejszym bezpieczeństwem i niższą jakością pracy. Opisywane w raporcie Państwowej Inspekcji Pracy częstsze wypadki osób pracujących w niestandardowych formach, brak wypłacania im wynagrodzenia za pracę w nienormowanych godzinach oraz porach pracy (brak dodatku za pracę w nocy i w weekendy) to jeden z przykładów opisywanej segmentacji ${ }^{46}$. Praca w ramach pozakodeksowych form zatrudnienia skutkuje również otrzymywaniem niższego wynagrodzenia za swoją pracę i częstymi przypadkami braku płatnego urlopu ${ }^{47}$, co potwierdza się w doświadczeniach respondentów badań własnych autora oraz innych badań społecznych.

Rozpatrując zgodność pracy w ramach umowy-zlecenia z przepisami dyrektywy Unii Europejskiej dotyczącej zamówień publicznych oraz ze strategią flexicurity, należy stwierdzić, że praca $\mathrm{w}$ tej formie nie zapewnia gwarancji praw socjalnych

${ }^{45}$ A. Laszek, W. Wojciechowski, wyd. cyt., s. 8.

46 Sprawozdanie Głównego Inspektora Pracy z działalności Państwowej Inspekcji Pracy - 2017, Warszawa 2018, s. 72-73.

${ }^{47}$ D. Bąk-Grabowska, Materialne warunki pracy pracowników zatrudnionych $w$ formach niestandardowych, [w:] Nauki ekonomiczne w XXI wieku-wyzwania, dylematy, perspektywy. Ekonomia, finanse, nauki o zarządzaniu, Prace Naukowe Uniwersytetu Ekonomicznego we Wrocławiu, nr 499, Wydawnictwo Uniwersytetu Ekonomicznego we Wrocławiu, Wrocław 2017, s. 14-15. 
i praw pracy gwarantowanych obywatelom spójności ze względu brak jej ochrony przez Kodeks pracy. Liczne przykłady nadużyć wykorzystywania pracowników pracujących w tej formie potwierdzają te założenia. Ze względu na powyższe okoliczności ustawodawca w Prawie zamówień publicznych podkreśla brak możliwości zatrudniania na umowie-zleceniu w momencie wystąpienia stosunku pracy, rozumianego w myśl kodeksu pracy jako „(...) wykonywanie określonej pracy na rzecz pracodawcy i pod jego kierownictwem oraz w miejscu i czasie wyznaczonym przez pracodawcę"48. Zakaz wyboru takiej umowy przez pracownika w momencie wystąpienia powyższego stosunku pracy, ze względu na znaczną przewagę wyboru umów pozakodeksowych wymuszanych na pracownikach, potwierdza zasadność wprowadzonych rozwiązań prawnych. Wymóg opisu charakteru zatrudnienia osób mających pracować przy zamówieniu, razem z obowiązkowym planem jego kontroli przy poszczególnych zadaniach, opisanym przez zamawiającego w treści SIWZ, ma na celu poprawę sytuacji pracowników w Polsce i eliminację przypadków zastępowania przez pracodawców umów o pracę umowami-zleceniami ${ }^{49}$.

Rygorystyczne podejście do kwestii zastępowania umów o pracę umowami cywilnymi wydaje się zasadne w świetle przedstawionych przez autora danych i badań opinii społecznej dotyczących deprywacji bezpieczeństwa socjalnego i ekonomicznego osób pracujących w niestandardowych formach zatrudnienia w Polsce. Potrzeba elastyczności umów zatrudnienia, odnosząca się również do pracowników i pracodawców wykonujących pracę w ramach zamówień publicznych, jest obecna w opiniach zarówno pracowników, jak i pracodawców, częściej wśród osób młodych. Określona w artykule sztywność umowy o pracę często nie jest zgodna z obowiązującymi praktykami dynamicznie zmieniającego się rynku pracy, dostosowanego do unijnego modelu flexicurity. Zwiększenie elastyczności rynku pracy w Polsce zostaje wprowadzone jedynie na poziomie powszechnego wykorzystywania przez pracodawców umów-zleceń, wbrew zakładanemu charakterowi umów cywilnoprawnych - mających pierwotnie służyć pracom dorywczym, bez stosunku świadczenia pracy, dla specjalistów z wysoką pozycją negocjacyjną. Do momentu zmiany opodatkowania poszczególnych form zatrudnienia oraz bez uelastycznienia umowy standardowej będzie zachowane status quo segmentacji rynku pracy w Polsce. Wszelkie próby prawne mające na celu ograniczenie wykorzystywania umów-zleceń do zatrudnienia w formie pracy kodeksowej wydają się zasadne w świetle unijnych gwarancji jakości zatrudnienia dla obywateli spójności. Jednak bez radykalnej korekty polskiej polityki rynku pracy, zmiany takie, jak zaprezentowane w artykule, nie będą mogły być w pełni skuteczne.

${ }^{48}$ Ustawa z dnia 26 czerwca 1974 r. - Kodeks pracy (Dz.U. z 2014 r., poz. 1502 z późn. zm.).

49 A. Bura, Artykut 29 ust. 3 A PZP. Wymóg zawierania przez wykonawców umów o pracę, Przetargi Publiczne, wrzesień 2017, Warszawa. 


\section{Literatura}

Bąk-Grabowska D., Piwowar-Sulej K., Flexicurity na tle założeń europejskiego i amerykańskiego modelu rynku pracy oraz polskich uwarunkowań, Nauki Społeczne, nr 1(5), red. J. Chumiński, Wydawnictwo Uniwersytetu Ekonomicznego we Wrocławiu, Wrocław 2012.

Bąk-Grabowska, D., Materialne warunki pracy pracowników zatrudnionych $w$ formach niestandardowych, [w:] Nauki ekonomiczne w XXI wieku - wyzwania, dylematy, perspektywy, Ekonomia, finanse, nauki o zarzadzaniu, Prace Naukowe Uniwersytetu Ekonomicznego we Wrocławiu, nr 499, Wydawnictwo Uniwersytetu Ekonomicznego we Wrocławiu, Wrocław 2017.

Boeri T., Ours J.V., Ekonomia niedoskonatych rynków pracy, Wydawnictwo Oficyny Wolters Kluwer, Warszawa 2011.

Bura A., Artykut 29 ust. 3A PZP. Wymóg zawierania przez wykonawców umów o pracę, Przetargi Publiczne, wrzesień 2017, Warszawa.

Daniłowska S., Duńskie państwo dobrobytu a koncepcja flexicurity, Instytut Polityki Społecznej, Warszawa 2016.

Frączak M. (red.), Polityka rynku pracy, teoria i praktyka, Polskie Wydawnictwo Naukowe, Warszawa 2015, s. 70-72.

Giermanowska E., Ryzyko elastyczności czy elastyczność ryzyka, instytucjonalna analiza kontraktów zatrudnienia, Wydawnictwo Uniwersytetu Warszawskiego, Warszawa 2013.

Gładzicka-Janowska A., Flexicurity - koncepcja i jej weryfikacja w okresie kryzysu i spowolnienia po 2007 roku, Optimum. Studia Ekonomiczne, 2013, nr 3(63).

Gyulavári T., Kártyás G., The Hungarian Flexicurity Pathway? New Labour Code after Twenty Years in the Market Economy, Pazmany Press, Budapest 2015.

Guzikowski M., Instytucje rynku pracy w krajach transformacyjnych. Dynamika, interakcje, prawidtowości empiryczne, Oficyna Wydawnicza Szkoły Głównej Handlowej, Warszawa 2016.

Klimczak B., Wybrane problemy $i$ zastosowania ekonomii instytucjonalnych, Wydawnictwo Akademii Ekonomicznej we Wrocławiu, Wrocław 2006.

Kryńska E., Kwiatkowski E., Podstawy wiedzy o rynku pracy, Wydawnictwo Uniwersytetu Lódzkiego, Łódź 2013.

Kucharski M., Koncepcja flexicurity a elastyczne formy zatrudnienia na polskim rynku pracy, Wydawnictwo Elipsa, Warszawa 2012.

Kwiatkowski E., Bezrobocie. Podstawy teoretyczne, Wydawnictwo Naukowe PWN, Warszawa 2007.

Kwiatkowski E., Wplyw prawnej ochrony zatrudnienia na rynek pracy w warunkach negatywnego szoku ekonomicznego, Gospodarka Narodowa, 2012, nr 11-12, s. 1-23.

Laszek A., Wojciechowski W., Propozycje zmian w zakresie umów o pracę: kodeksowych i cywilnoprawnych, Forum Obywatelskiego Rozwoju, nr 3, Warszawa 2015, s. 2-8.

Maydell B.V. (red.), Enabling social Europe, Springer, Berlin 2006, s. 112-113.

Męcina J., Niewykorzystane zasoby rynku pracy. Nowa polityka rynku pracy, Wydawnictwo ASPRA-JR, Warszawa 2013.

Muster R., Elastyczne formy pracy w opiniach pracowników nieetatowych, Opuscula Sociologica, nr 1, Katowice 2012.

Sadowska-Snarska C., Elastyczne formy pracy jako instrument ułatwiajacy godzenie życia zawodowego z rodzinnym, Wydawnictwo Wyższej Szkoły Ekonomicznej w Białymstoku, Białystok 2006.

Sánchez Á.L., Analiza społecznych i ekonomicznych skutków nietypowych form zatrudnienia w Unii Europejskiej na przykładzie Hiszpanii, [w:] Elastyczny rynek pracy i bezpieczeństwo socjalne, flexicurity po polsku?, red. M. Rymsza, Wydawnictwo Instytutu Spraw Publicznych, Warszawa 2005.

Standing G., Prekariat: nowa niebezpieczna klasa, Wydawnictwo Naukowe PWN, Warszawa 2014. Stankiewicz W., Historia myśli ekonomicznej, Polskie Wydawnictwo Ekonomiczne, Warszawa 1987. 
Wilthagen T., Tros F., The concept of ,flexicurity”. A new approach to regulating employment and labour markets, Flexicurity Research Paper, 2003/2004.

\section{Źródla prawa}

Ustawa z dnia 29 stycznia 2004 r. - Prawo zamówień publicznych (Dz. U. z 2018 r., nr 19, poz. 1986 z późn. zm.).

Ustawa z dnia 26 czerwca 1974 r. - Kodeks pracy (Dz. U. z 2014 r., poz. 1502 z późn. zm.).

Ustawa z dnia 23 kwietnia 1964 r. - Kodeks cywilny (Dz. U. z 2018 r., poz. 1025, 1104, 1629, 2073).

\section{Źródla internetowe}

https://www.prawo.pl/samorzad/klopotliwy-wymog-zatrudnienia-na-umowe-o-prace-w-nowelizacjipzp,232298.html (dostęp 13.12.2018 r.).

https://www.gov.pl/web/rodzina/placa-minimalna-w-gore (dostęp 13.12.2018 r.).

https:/www.uzp.gov.pl/baza-wiedzy/interpretacja-przepisow/opinie-archiwalne/opinia-dotyczaca-art.-29-ust.-3a-ustawy-pzp (dostęp 13.12.2018 r.).

https:/www.pwc.de/de/prozessoptimierung/assets/millennials-at-work-2011.pdf (dostęp 13.12.2018 r.). https:/www.gov.pl/web/rodzina/informator-zmiany-w-oskladkowaniu-umow-zlecenia (dostęp 13.12. 2018 r.).

\section{Raporty}

Elastyczne formy zatrudnienia - skutki społeczne i ekonomiczne, Wydawnictwo „Obserwatorium Dolnośląskiego Rynku Pracy i Edukacji”, Wrocław 2013.

Flexicurity w Polsce - diagnoza i rekomendacje, red. nauk. E. Kryńska, Warszawa 2009.

GUS, Notatka informacyjna. Pracujacy w nietypowych formach zatrudnienia, Warszawa 2016.

GUS, Pracujacy w gospodarce narodowej w 2017 roku, Wydawnictwo Głównego Urzędu Statystycznego, Warszawa 2018.

Sprawozdanie Głównego Inspektora Pracy z działalności Państwowej Inspekcji Pracy - 2017, Warszawa 2018. 